\title{
Euskal toponimia, baserrien izenak eta deituren ondarea, Gizarte-Zientziak ikasteko abiapuntu. Bigarren hezkuntzarako proposamena
}

\author{
Ana Isabel Ugalde \\ Joseba Arregi Orue \\ Gizarte Zientzien Didaktika Saila \\ Hezkuntza eta Kirol Fakultatea \\ Euskal Herriko Unibertsitatea (UPV/EHU)
}

DOI: $10.1387 /$ tantak.16340

GAKO-HITZAK: Gizarte Zientzien ikaskuntza-irakaskuntza, toponimia, baserri izenak, euskal deiturak, jabetza pribatua, Bigarren Hezkuntza, IKT.

\section{SARRERA}

Eskola curriculumetan maiz aipatzen da Euskal Herriko umeek ondarea ezagutu, balioetsi eta errespetatzen ikasi behar dutela, ondare materiala zein ez-materiala, artistikoa, monumentala, historiko edo kulturala. Eta toponimiari dagokionez, 2007an Nazio Batuek aldarrikatu zuten Izen Geografikoen Normalizaziorako eginiko IX Biltzarrean izen horiek ondare kultural ez-materiala direla eta, horregatik, gorde beharreko ondasun.

Hain lotura estua izan arren Geografia eta Historiarekin, beste diziplina akademiko batzuen artean, toponimiak ia ez du lekurik gure esparruan eragina duten Gizarte Zientzietako curriculum ofizialetan, ez modu zuzenean ezta zeharka ere. Eta eskolan, aintzat hartzen denean, gehienetan izaten da banakakoen ekimenaren ondorioz.

Toponimiak eskaintzen dituen aukerak ingurua hobeto ezagutzeko ukaezinak dira. Gure lanean proposamen bat egin gura diegu Gizarte Zientzietako irakasleei, Derrigorrezko Bigarren Hezkuntzako edo Batxilergoko geletan inplementatzeko, soil soilik kontuan izanda kortak edo saroiak, aspaldian lurraldea antolatzeko eratutakoak.

Ez dugu unitate didaktiko bat eskainiko kortok edo saroiok zer ziren ikasteko, ariketa edo ekintzen zerrenda bat emanda, ezta zein metodologia 
edo estrategia didaktiko erabili ere. Aitzitik, irakasleak ohartarazi nahi ditugu gaiak dituen posibilitate didaktikoez, bere berariazkotasuna eta potentzialtasuna tarteko, diziplina akademiko ezberdinei heltzeko: Zelan eratorri diren toponimo batzuk antzinako espazioaren antolamendu berezitik, asko landa eremuetan kontserbatu direnak eta euskaldun askok deitura moduan daramatzatenak. Gainera, nahiz eta mendeak pasatu diren sortu zirenetik, oraindik samur ikus daitezke urrutitik euren forma biribilak — ez bakarrak, Baztanen karratuak ere badirelako-, mugak zehazteko erabiltzen diren mugarriak ere ikus daitezke basoan, eta samurrago oraindik, teknologia digital berriei esker.

\section{TOPONIMIA, GIZARTE ZIENTZIAK IKASTEKO ETA IRAKASTEKO BALIABIDE APARTA}

Toponimiaren erabilera eskoletan gero eta ohikoagoa da ingurunea hobeto ulertzeko, bai martxan jarritako esperientziak direla edo proposamen gisa eskainitakoak (Friera, 1992; Torres, 1995; Comes \& Dantí, 2003; Tort, 2001, 2004; Ubieto, 2007; Særheim, 2004; Comerci, 2012; Gómez, Sevilla \& Hernández, 2015). Normala den lez, leku izenak bere baitan ditu lurraldearen ezaugarri fisikoak eta han bizi izan diren gizon-emakumeek sortuak. Izan ere, gizatalde batek espazio jakin bati buruz duen kontzepzioaren berri ematen du bere izenak, baita bertan jazotako prozesuen eta berezi egiten dutenen berri ere bai (Fernández, 2006; Ubieto, 2007; Lleonart, 2008; Villalón, 2013).

Bedoyak (2006) dioen bezala, izenek pertsonek duten munduaren pertzepzioa islatzen dute, zeina kulturaren emaitza den. Horrela, giza jarduera asko paisaiari atxikita geratzen dira toponimo edo izen geografiko moduan, espazioak eta denborak bat eginaz. Toponimoek parajeak sozializatu egiten dituzte eta kulturaren zati bihurtu, anonimotasunetik aterata, eta memorian eta historian sartuta.

Bere izaera utilitarioa dela eta, diziplinartekotasuna behar da ikerketari ekiteko (Tort, 2001), paisaiaren eta bertan bizi direnen ulermen egokiagoa errazteko (Sanz, 1992). Horregatik, toponimiak eskaintzen dituen aukerak itzelak dira, hezkuntzako edozein etapatan eta edozein ikasgaitan erabilera pedagogikoa emateko (Friera, 1992; Mas-i-Miralles, 1999; Valenzuela, 2010).

Toponimoak erabiltzeko dugun erraztasunak ezin diezaguke galdu arazi ikasleentzako zein inportantea den egunerokoaren gaineko ezagutza, gaurko eta aspaldiko gizataldeak hobeto ulertzeko, eta kokatzen diren ingurunea ere konprenitzeko (Estepa, Cuenca \& Martín, 2011). Toponimiaz oso maiz baliatu izan dira hainbat ikertzaile eta didakta, esaterako, Geografia, hizkuntzak edo Natur Zientzien irakasleak. Gutxiago, ordea, Historia edo beste Gizarte Zientzietakoak, arkeologoak izan ezik. Guk hori egingo 
dugu, alegia, gure proposamena gauzatzerakoan, espero dugulako toponimoek edo, zehatzago esanda, baserri izenek ikasleen jakin-mina piztuko dutela, euren antroponimoari zuzen zuzenean eragiten dietelako.

\section{E.A.E.KO ESKOLA CURRICULUMA: ONDAREA ETA TOPONIMIA}

Interesgarria litzateke jakitea zer dioen E.A.E.n indarrean dagoen eskola curriculum ofizialak (EHAA / BOPV, 175/2007 eta 97/2010 dekretuak) ondareari eta toponimiari buruz. Nabarmena da Euskal Herriko hizkuntzari eta kultura ondareari egiten zaion erreferentzia, horiek ezagutzea, balioestea eta errespetatzea izanik xedea, eta xede horiek betetzea gainerako kultura eta gizarteekiko. Oso zentzu zabala ematen zaio ondareari, kultural izenondoak ondare soilari esangura integratzaileagoa gehitzen diolako (González \& Pagès, 2005). Curriculuma garatzerakoan, ondare kulturaltzat aitortzen dituzte ondare linguistikoa, historikoa, artistikoa, arkeologikoa eta naturala. Inplizituki bada ere, ondare materiala eta ez-materiala, zeinean toponimia sartuko genukeen. Zeregin handia, definizio zabala eta malgua delako eta, aldi berean, urria, zehaztu gabea delako.

Toponimiak berak ez du aipamen askorik. Behin baino ez, erromatar jatorrikoa zehazten denean, Kultura Klasikoaren ikaskuntza-irakaskuntzaren azalpenean. Ez da askorik, jakinik Kultura Klasikoa aukerako irakasgaia dela Derrigorrezko Bigarren Hezkuntzako bigarren zikloan eta, horregatik, ikasleengan eragiteko posibilitateak murritzagoak direla.

Hona, hitzez hitz esaten dena:

«Irakasgai honetan, leku garrantzitsua izan behar dute Euskal Herrian dauden erreferentzia klasikoek; adibidez, testigantza idatziek, aztarna arkeologikoek, toponimia-terminoek, eta abarrek. Eduki mota horiek ikasiz gero, ikasleek hobeto ezagutuko dute beren burua, gizabanako nahiz kolektibo gisa, eta beren ondarea balioesten eta zaintzen ikasiko dute, bai eta beste herri eta gizabanako batzuei ezagutarazten ere» (Haur hezkuntzarako, lehen eta bigarren hezkuntzarako eta batxilergorako dekretu currikularrak Euskal Autonomia Erkidegoan, 2010: 823)².

Ezer ez dago esaterik horren kontra. Bai, ordea, bertako toponimiaren baliagarritasuna aldarrikatzea, erromatar jatorriko toponimiarekin bezala, ikasleek euren burua hobeto ezagutzeko, gizabanako nahiz kolektibo gisa, eta beren ondarea balioesten eta zaintzen ikasteko, bai eta beste herri eta gizabanako batzuei ezagutarazteko.

1 http://www.hezkuntza.ejgv.euskadi.eus/r43-5473/eu/contenidos/informacion/dia2/ eu_2023/adjuntos/decretos_curriculares/dc_educ_basic_e.pdf, 823. Or. 
Gogoratuz Nazio Batuen Erakundeak 2007an toponimoak Gizateriaren ondare ez-material izendatu zituela eta, horregatik, babestu beharrekoak direla, Euskal Herrian hainbat ikerketa lan egin dira asmo horrekin, Euskaltzaindiaren zuzendaritzapean. Ikerketok denetariko formatuetan gauzatu dira, mapa, plano, kale izendegiak, monografikoak edo bestelako dokumentuak eginaz (Galé, 2007). Tamalez, beste diziplina askotan gertatzen den moduan, salbuespenak salbuespen, ez dira eskolara heldu.

Eta Historiaren irakaskuntzari erreparatzen badiogu, Valls eta LópezFacalek (2010) diote gure inguruko eskola gehienetan ohitura eta praktika tradizionaltzat jo daitezkeenak bateratsu ematen direla berritzaileagoak direnekin, nahiz eta hauek bakanagoak izan. Xx mende amaieran ezarritako berrikuntzarik behinena curriculum ofizialetan eduki instrumentalak sartzea izan zen, diziplina bakoitzaren berariazko prozedura eta teknikak, ikasleak euren kabuz ikasteko trebatuko zirelakoan. Eskolako liburuek, material didaktiko nagusiak zirenak, irizpide hauek jaso zituzten, baina oso modu partzialean, gehigarri gisa baino ez. Guzti horren ondorioa izan zen gai multzo handia eskaintzea, ikuspegi sinple batez landuta eta trataera didaktiko azalekoaz.

Hurrengo egindako erreforma eta aldaketek antzeko ideiak garatu dituzte XXI mende hasi berrian gauzatu diren curriculumetan. Eta oinarrizko zortzi gaitasunek diotenaz indarra jarri da «egitean» eta «egiten jakitean» (Trigueros, Ortuño \& Molina, 2015). Euskal Herriko eta Espainiako curriculumek jasota dituzte funtsezko ideia horiek eta Berritzeguneetan ematen diren orientabideak ere tenore berekoak dira ${ }^{2}$. Baita LOMCE eta HEZIBERRI $2020^{3}$, Eusko Jaurlaritzak eztabaidarako aurkezturiko dokumentua ere.

Dena dela, gaitasunak edo konpetentziak lortzeko ez da nahikoa legea egitea. Ezinbestekoa da edukiak ere xede horiek lortzeko aproposak izatea, pentsamendu eta kontzientzia historikoa sustatzea. Datuak, datak eta lekuak ikastea baino gehiago eskaini behar zaie ikasleei, beste kontzeptu estrategiko batzuk. Eduki historiko itxi eta bukatuekin amaitu beharra dago, interpretaziorik eskatzen ez duten eduki historikoekin. Eta lortu behar dira gogoeta egiteko beste trebezia batzuk, pentsamendu historikoa sortzeko baliagarriak direnak (Trigueros, Ortuño \& Molina, 2015).

2 Ley Orgánica 3 Mayo de 2006, Real Decreto 1631/2006, EHAA / BOPV, 175/2007 eta 97/2010 dekretuak, http://nagusia.berritzeguneak.net/gaitasun/docs/orientaciones/ ciencias_sociales.pdf

3 Ley Orgánica 8/2013, de 9 de diciembre, Real Decreto 1105/2014, de 26 de diciembre; http://www.berrigasteiz.com/site_legeria/docs/kurrikuluma/20131209_ lorg_082013/20150218_bopv_decreto_xx_2015_kurrikuluma_oinarrizkoa_v1_ eranskina_c.pdf, https://www.dropbox.com/s/i2d2nnh1mlkhtuy/4_Anexo_Educacion_ Secundaria_Obligatoria.pdf?dl=0 
Edozein delarik arrazoia, irakasleriaren formazio historiografikoa nagusi delako, eta ez didaktikoa, edo erabilitako testu liburuetan ez dituztelako edukiok sartu, Derrigorrezko Bigarren Hezkuntzako ikasleek (espainiarrek, inguruko Europako herrialdetakoek zein iberoamerikarrek) berresten dute Historiako eskoletan ez dela aldaketa nabarmenik gauzatu, oraindik ohitura dela irakaslearen eduki bukatuen transmisioa. Ia jarduera bakarrak omen dira azalpenak, irakurketak eta testu liburua estudiatzea. Ikasleentzako Historia ikasgaiaren funtsa ei da gertakizun historiko batzuen inguruan jira-biraka ibiltzea, behin eta berriz saiatzea eta horien inguruko informazioa buruz ikastea. Historiak ez ei du ezertarako balio, ez bada dotore itxura emateko (Valls \& López-Facal, 2010).

Eta ebaluazioari begiratzen bazaio ere, Murtzian D.B.H.ko 3. eta 4. mailako ikasleekin egin berri den ikerketa batek frogatu lez, eskolan entzun edo testu liburuetan irakurritakoa errepikatzea da gehien eskatzen zaiena. Horrela, ez dago pentsamendu historikoa garatzerik, hausnarketarako eta kritikarako bideak zabaldu ezean (Trigueros, Ortuño \& Molina, 2015).

Testu liburuen aipamenak (digitalak edo paperezkoak) oso ugariak dira, eskoletan gehien erabiltzen den material didaktikoa direlako. Onartu beharra dago arras aldatu direla, onerako. Gehitu dituztela iturri historikoak, dokumentuak, eta horiekin lan egiten ikasteko ariketa eta jarduerak, ikasleak teknika historiografikoekin trebatzeko. Baina ezin da ahantzi material komertzialak direla, publiko zabal batentzako eginak, zeinetan hobesten diren eduki akademikoak didaktikoen gainetik, segurutik irakasleak erosoago sentitzen direlako historiagile gisa, didakta baino (Valls \& López-Facal, 2010).

Badago beste gai eztabaidagarri bat testu liburuei dagokiena. Ondareari ematen zaion trataeraz ari gara, alegia, ondarea ikaskuntzaren ardatz egituratzaileaz, egungo eta aspaldiko giza taldeen ezagutzarako iturri. Ondarea eduki sozio historikotzat har daiteke, erabiltzen bada ikuspuntu sinboliko, nortasun eragile eta kulturen bateratzaile moduan (Estepa, Domínguez \& Cuenca, 1998; Estepa, 2001).

Eskolako liburuak, izatez, material estandarrak dira. Ez dute ia lekurik berariazko gaietarako, konkretu edo gertukoentzako; ondarea dela, oro har, edo toponimia dela, zehazki. Gizarte Zientziak, Geografia eta Historiako editorial desberdinetako liburuek ondarearen hezkuntzari ematen zioten trataera ikusteko Espainian egindako estudio batean, ondarea zentzu holistiko, sinboliko eta nortasun eragile moduan hartuta, ondorioztatu zuten ondareaz baliatzen zirela anekdota gisa, munduan ezagun ziren elementuak goratuta, baina lotura sozial barik. Eta komunitate autonomoa kontuan izanda ere, ez zen sumatu alderik (López, 2013).

Urte batzuk lehenago, antzeko ikerketa bat burutu zuten Katalunian (González \& Pagès, 2005) eta emaitzak parekoak izan ziren. Haren aburuz, ondarea ez da baliabide gisa erabiltzen ezagutza soziala eta historikoa eraikitzeko. Bitxikeria moduan baino ez, teoriaren lagungarri edo ekintza lu- 
diko edo hezitzaileren bat egiteko. Ikaskuntza-irakaskuntza prozesuan ez da prozedurazko erreferentzia bat. Ez da irakasten ikaslearengandik gertu dagoen ondareaz jabetzen, analizatzen, balioesten edo kontserbatzen. Ondare kulturala ez da abiapuntu interpretazio orokorrak eraikitzeko, beste leku eta errealitate batzuk ulertzeko. Ondarea ez da lotzen jarrerak garatzearekin, behin eta berriz esan arren zein garrantzitsua den balioestea eta kontserbatzea, sekula ez delako ekintza zehatzetan gauzatzen. Historialariek iturriekin nola lan egiten duten ere ez da azaltzen. Testua beti da narrazio itxia, banakako ariketak proposatzen dituena, iritzi desberdinak eta aurkakoak kontrajartzeko leku gutxi uzten duena. Finean, ez dute laguntzen ezagutza sozial eta historiko arrazoitua eraikitzen.

Ez dugu ezagutzen gai zehatz hauen inguruan Euskal Herrian egindako ikerketarik. Hala ere, hemen erabiltzen diren testu liburuen edukiak aztertu dituztenek (Ezkurdia-Arteaga, Pérez-Urraza \& Bilbao-Bilbao, 2006) diote Euskal Herriari lotutakoak \%19 baino ez direla, estatuarekikoak \% 34a diren bitartean, eta tendentzia beheranzkoa dela. Oro har, ikuspegi turistikoa, folklorikoa agertzen ei dute testuliburuek, nortasunari eta identitateari lotuen dauden ezaugarriei presentzia txikia emanez. Gainera, kontuan izanda liburuen $\% 61$ behintzat Euskal Herritik kanpoko editorial handiek egiten dituztela, ondoriozta daiteke aurrez mahaigaineratu ditugun arazo antzekoak jazoko direla hemen ere. Eta paisaiari dagokionez, gehien erakusten den edukia izanik, eta Lehen Hezkuntzako liburuak arakatu badira ere (Pérez-Urraza, Ezkurdia-Arteaga, Bilbao-Bilbao, 2015), esan behar dugu erreferentzia sozio-kulturalak dituztenak oso urriak direla, nahiz eta emaitza hobexeagoak ematen dituzten euskaraz sortu eta idatzi diren liburuek. Tamalez, hauek ere gainbeheran.

Bat gatoz Barrosekin (2008) esaten duenean ikasleek edozein motatako iturriez baliatu behar dutela, Historia ikertzaileak egingo lukeen moduan. Derrigorra da bateratzea Historia ikasia eta Historia ikertua, hots, irakasleak gidaturiko auto-aprendizgoa, historialariaren iturriak erabiliz, ikasleriari irakatsiz Historia zelan egiten den, egilearen ikuspuntua hartuta eta ez irakurlearena. Datuak antzematea, askoren artean hautatzea, testuinguru batean kokatzea eta horietatik eratorritako emaitzak plazaratzea eta eztabaidatzea, modu traketsean bada ere, berebiziko inportantea da historialariaren lana gerturatzeko eta gazteei laguntzeko kritikotasuna eskuratzen eta ez Historia idatziaren absolututasuna ontzat ematen. Gainera, ezin dugu ahaztu Historia egin ahal izateko dokumentuak, ideiak, iturriak eta sormena behar direla (Le Goff, 1983).

Horregatik, gure proposamena Historia, eta aldi berean Geografia eta beste Gizarte Zientzia batzuk, ikasi eta irakasteko aukera bat eskaintzea da, D.B.H.ko edo Batxilergoko ikasleen errealitatean sustraitutakoa: bere nortasunari eragiten diolako arbasoengandik jaso duen deiturak edo abizenak. Abiapuntua izango da deituraren jatorria arakatzea eta oinarrian egongo da toponimoekin egin beharreko lana, zehatzago esanda, baserri izenekin, ahaztu gabe iturri artxibistikoak eta kartografikoak. Deweyk zioen bezala, 
iragana eta bere herentzia ezagutzea oso esanguratsua da orainean sartzen bada, eta ez bestela (Dewey, 1929. In Calaf, 2009).

\section{DEITURA ETA ETXEA EUSKALDUNEN ARTEAN}

Aurrera egin baino lehen, berba batzuk eskaini behar dizkiegu deiturak eratzeko euskaldunen artean egon den ohiturari, toponimo askok etxeari izena eman diotelako eta, ondoren, abizen bilakatu direlako. Hori dela eta, toponimo edo oikonimo anitz (oikos, etxea eta onimo, izena) euskaldun askoren antroponimo dira.

Euskal Herriko zati handi bateko etxe tradizionala baserria da, unitate ekonomiko eta familiarra, etxeak eta bere ondasunek osatzen dutena. Baserriaren ezaugarri behinenetarikoa da izen berezia izatea, kasurik zaharrenetan etxea kokatuta dagoen topografiaren, geologiaren edo naturaren berri ematen duena. Izenok, oikonimook, denboran zehar aldaketa gutxirekin heldu dira gaur egunera arte, nahiz eta ugazabak aldatu edo etxea berreraiki. Horregatik, baserriaren biografia dokumentala oso aspaldira arte egin ahal izaten da (Santana, Larrañaga, Loinaz \& Zulueta, 2002). Dirudienez, identifikatzeko beharrarekin batera, faktore desberdinek indartu zuten etxe bakoitza bereizteko premia. Horien artean leudeke etxea izatea landa eremuetako gizataldeak antolatzeko oinarrizko elementua, oinordeko bakarraren figura eta herritartasun eskubidea edukitzea etxe kopuru zehatz batek (Itulain, 2005).

Jatorri desberdineko etxe izenak daude eta, kokapen geografikoaren arabera, gailendu dira batzuk edo besteak. Jabearen izena dela (Perurena, Migelena edo Jonsansoro modukoak), ogibidea dela (Arotzarena, Barberena edo Apezarena modukoak), etxearen ezaugarriak (Etxazarreta, Etxabarri, Etxazuri, Etxaluze) eta abar. Eta asko eta asko dira etxea eraiki zeneko parajearen izena hartzen dutenak (Salaberri \& Zubiri, 2009; Itulain, 2005).

Etxeak lekuaren izena hartzea batez ere gertatzen da Bizkaian, Gipuzkoan, Arabaren eta Nafarroaren iparraldean eta Ipar Euskal Herrian, hau da, populazio barreiatua duen landa paisaian. Kontua da Behe Erdi Aroan eta batez ere XVI mendetik aurrera, arrunt bilakatu zela pertsonaren izenari etxearen izena gehitzea abizen gisa. Hasieran, goi mailako jendeak egin omen zuen hori, eta gero, jende arruntak. Jatorrizko formula izaten zen antroponimoa osatzea izenak, patronimikoak eta etxearen izenak. Polito polito, gorabehera askorekin, patronimikoa galduaz joan zen eta etxearen izena geratu zen abizentzat. Eta abizen edo deitura hori bihurtu zen familia edo leinuari deitzeko modua, etxearen jabe izan ala ez (Ros, 2013; Salaberri \& Zubiri, 2009).

Adibide bat erabiliko dugu esan nahi duguna hobeto azaltzeko asmoz. XV mendean Maria izeneko andrea, Pe(d)roren alaba eta Asube etxekoa bazen, María Pérez de Asube moduan agertuko zen paper idatzietan. Mende bi geroago, Maria de Asube izango zen. Eta gaur egun bizi izan balitz, Maria Asube. Euskaldun hiztunen artean, berriz, Maria Asubeko. Antroponi- 
moak mozteko tendentzia orokorra izan bazen ere, badira oraindik forma zaharrak bere horretan iraun dutenak.

Horra hor burubide historikoa, aldaketa eta iraunkortasunarena. Baserri asko desagertu egin dira. Deiturak ere bai. Iraun duten baserri gehienek bere jatorrizko izena, aldaerak aldaera, kontserbatu dute. Euskaldun askoren deitura dira baserri izenok, nahiz eta ez izan baserrion jabe. Eta oso jabe gutxik darama deituratzat etxe horren izena. Badago beste arazo bat eta da, toponimoak izaki, etxe askok oikonimo bera izatea. Eta badira baserriak, berriagoak, deiturarik sortu ez dutenak ere. Buruhauste ederra!

Zerbait argitze aldera, adibide batzuk jarriko ditugu. Lehen aitatu dugun Maria Perez de Asube benetako andre bat izan zen. 1626an bere izena dokumentatzen da Asencio de Madinabeitia bere ilobak auzitan sartu zuelako herentzian hartutako etxearen erreklamazioa ${ }^{4}$. Asube deitura XV mendean agertu zen dokumentuetan, baina XVII mendean desagertu egin zen. Etxeak, berriz, badirau Mondragoen (Gipuzkoa).

Arras desberdina da izen bera duten oikonimoak eta eratorritako deituren kasua. Esateko, Arteaga abizena hartuko bagenu, badira Euskal Autonomia Erkidegoan (EAE) izen bereko 21 baserri etxe (Rementeria, 2015). Eta Arteaga abizen zehatz baten zuztarrak non dauden jakin nahi izanez gero, ikertu beharra dago.

Esan berri dugun bezala, Asube deitura XVII mendean desagertu egin zen, eta beste muturrean leudeke 2014ko urtarrilean Espainian Arteaga lehen deitura moduan zuten 8495 pertsonak $^{5}$.

Bitxia da ere etxe berriaren aipamena duten deiturak. Euskalkia, denborak eragindako bilakaera eta idazkeraren arabera, honako datuak jaso ditugu 2014ko urtarrilean Espainian: lehen abizentzat zuten Echevarria 7.824 pertsonak; Etxebarria, 2.707k; Chavarri, 1.055ek; Chavarria, 2.045ek; Echeverria, 7.997k; Etxeberria, 2.996k; Echeverri, 805ek eta Etxeberri, 9k ${ }^{6}$.

\section{EUSKAL HERRIKO KORTA EDO SAROIEN BERARIAZKOTASUNA}

Ez gara luzatuko baserriak eta deiturak lotzen dituzten adibideak erreskadan ematen. Hori bai!, esan beharra dago deitura bihurtu diren baserri horien gehienen jatorria korta edo saroietan dagoela, paisaian aspaldi eratutako forma biribiletan 7 . Forma horiek Iberiar Penintsulako iparraldean

\footnotetext{
${ }^{4}$ Archivo de la Real Chancillería de Valladolid. Pleitos Civiles. Escribanía Varela. Pleitos Fenecidos. C 2416/6.

${ }^{5} \mathrm{http}: / / \mathrm{www}$. ine.es/apellidos/formGeneralresult.do? $\mathrm{L}=0 \& \mathrm{vista}=1 \&$ orig=ine \&cmb3 $=99$ $\& \mathrm{cmb} 6=$ arteaga $\& \mathrm{x}=9 \& \mathrm{y}=$

${ }^{6} \mathrm{http}: / / \mathrm{www}$.ine.es/apellidos/formGeneralresult.do?vista=1

7 Adibide gisa, argi diote Mondragoeko Aranguren izeneko baserriari buruz 1665ean, Mateo Nicolás Aranguren Andicano Santiagoren Zaldun izendatzeko espedientea osatzeko egindako datu bilketa batean, «con su término redondo como
} 
zehar ikus daitezke, Asturiasen hasi eta Orreagaraino, behintzat, eta Ipar Euskal Herrian ere bai. Nahiz eta tituluan soilik kortak edo saroiak jarri, euskaraz ematen zaizkien izenak dira korta, gorta, saroe, saroi, sarobe, soro, solo, xara, xarodi, busto, kaiolar edo olha, besteak beste. Eta izenok hainbat toponimo eta oikonimoren zati dira.

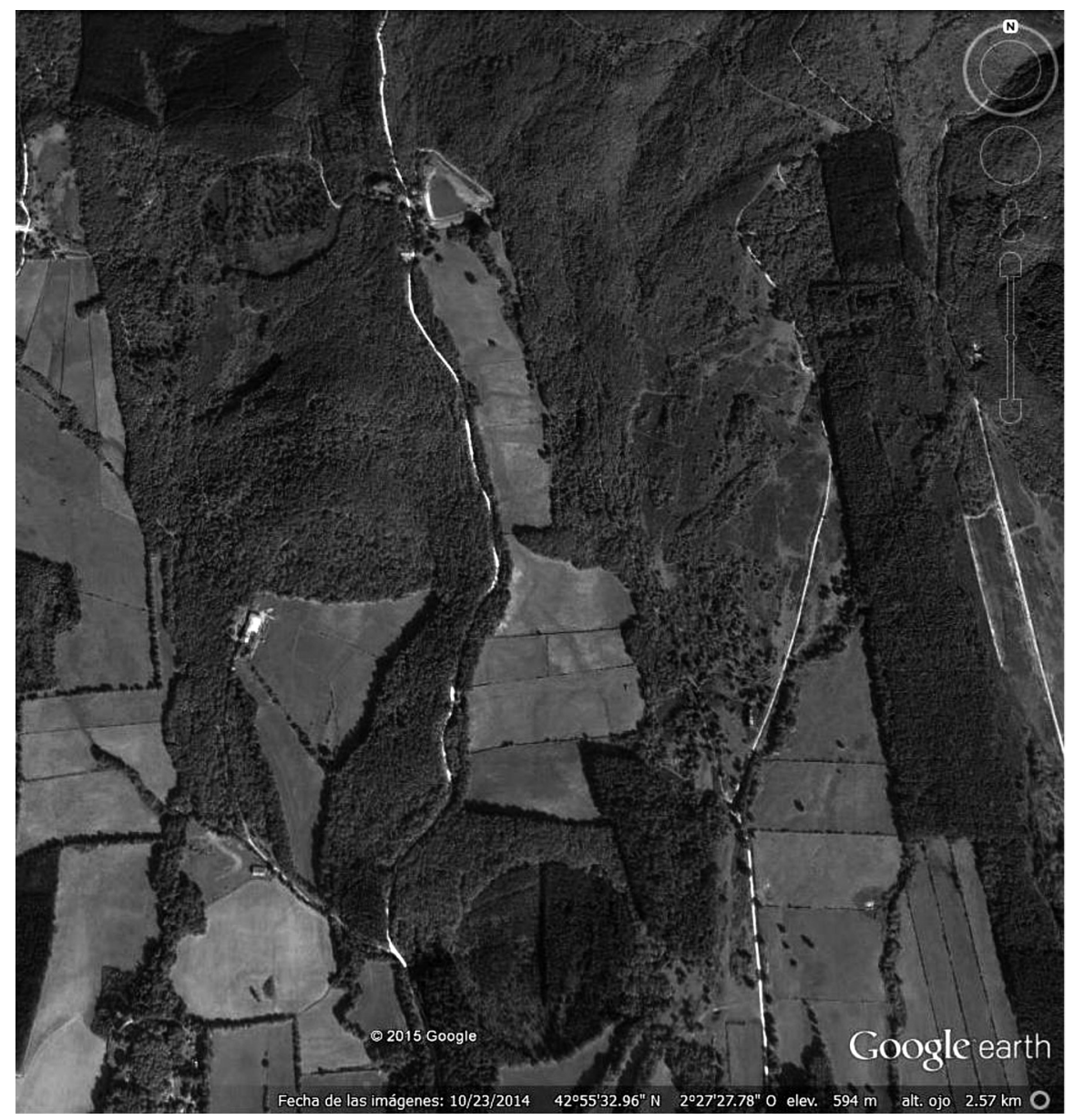

1. irudia

Baso ustiapenerako korta bi Barrundian (Araba).

2015eko urriaren 30ean eskuratua, https://www.google.es/intl/es/earth/index.html

casa solariega que es», hots, korta biribil batean zuela jatorria etxe horrek eta hangoek eta beren ondorengoek Aranguren deitura zutela. Archivo Histórico Nacional, Consejo de Órdenes, OM-CABALLEROS_SANTIAGO, Exp. 523, 3v-4r. 


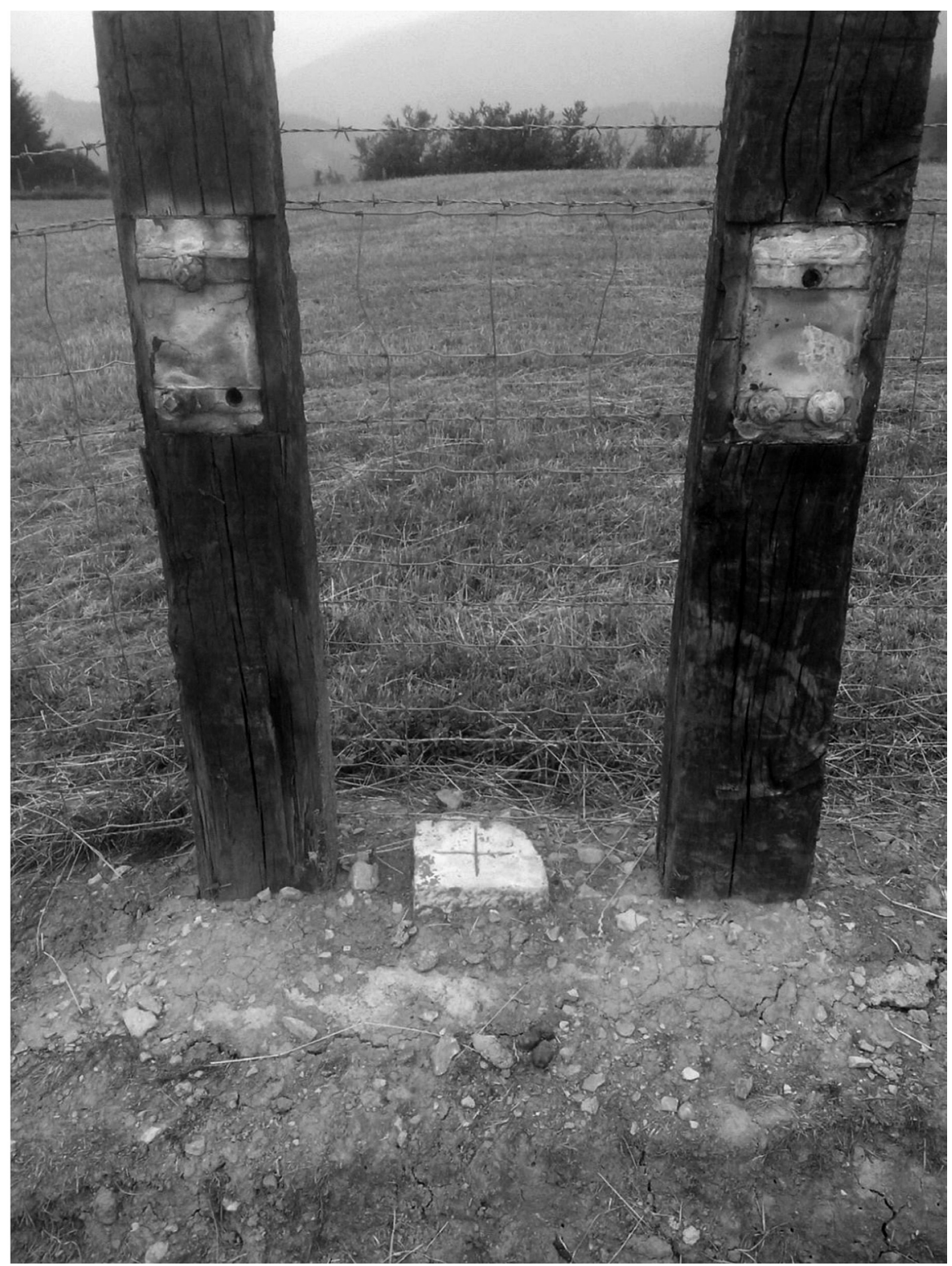

2. irudia

Aramaioko Untzilla auzoko (Araba) bide kontra batean dagoen bazter-mugarria.

Argazkia: I. Azkoaga 
Euskal historiografia oparoa izan da gaia tratatzerakoan. Ikerketa lan asko egin da, eta guk oinarri moduan hartuko ditugu Zaldua (2006), Gogeascoechea, Juaristi \& Moro $(2009,2010)$, Rementería \& Quintana (2010) eta Santanaren (2011) lanak. Interesa duenarentzako, gaiaren sintesi ona eskaintzen dute, bibliografia eta iturri dokumental ugari.

Sinplifikatzeko, izen bakarra erabiliko dugu, kortaz baliatuko gara, alegia. Gainera, komeniko litzateke gogoratzea euskaldun askoren artean guztiz hedatuta dagoela korta deitzea baserri etxean ganaduak gordetzeko lekuari. Baina gure aurrekoek etxeko leku horri beste izen batzuk eman izan dizkiote: ukuilu, ikuilu, ittu(b)a edo besteren batzuk. Badirudi kortak lekua jan diela aurrekoei eta lehen bereizi egiten baziren, gaur ia zeharo galduak ditugu bataren eta bestearen arteko desberdintasunak. Hala ere, gu aspaldiko korten inguruan arituko gara.

Ez da ezaguna zein den euren jatorria, baina korten paisaia oso antzinatik planifikatutako paisaia kultural iraunkorra da. Ikertu dituztenek diote biribilean prestaturiko eremuak direla, erdian ezarritako mugarri baten arabera eginak (1. irudia). Mugarri horri artamugarri, kortarri, hauts-harri edo hausterretza deitu izan zaio, han sua egiten zutelako, ganadua larrean zegoen bitartean. Eta kanpoan ere, zirkunferentziaren bueltan beste 4 edo 8 bazter-mugarrik zehazten zuten kortaren eremua (2. irudia). Neurri estandarrak zituzten eta bereizten ziren korta osoak eta korta erdiak, negukoak eta udakoak. Hasieran abeltzaintzarako izaten ziren, behi eta behorrentzako batez ere. Eta XV mendetik aurrera, nekazaritza eta baso ustiapenerako (3. irudia). Adituek ez dute zalantzarik esaten dutenean komunaletan pribatizatutako lehenengo sailak izan zirela. Eta jabetza pribatu biribil horietan, nekazaritzaren garapenarekin batera, Erdi Aroaren amaieratik aurrera dago baserrien jatorria eta, beraz, oikonimoena eta euskal deitura askorena.

Mendeak pasatu dira harrezkero eta Euskal Herriko landa paisaia errotik aldatu da, baina oraindik erruz ikus daitezke jabetza pribatu biribil horiek, batzuk zehatzak eta ikuserrazak, eta asko eta asko zeharo itxuraldatuta eta galduta. Hainbatetan gaur egun ere larre eta baso ustiapena dago, inongo eraikuntzarik gabe. Eta beste horrenbestetan, baserria (4. eta 5. irudiak). Jabetza zehazten duten mugarriak ere behin baino gehiagotan aurki daitezke baso eta larreetan (2. irudia).

Kortak edo saroiak oso leku aproposetan egoten dira: aldats gutxikoetan, eguzki-begian, ipar haize gordean, ura gertu edukitzen dute eta zuhaizti ederrak, animaliak gorde eta babesteko. Berdin topatu genitzake ibarretan edo mendian gora. 


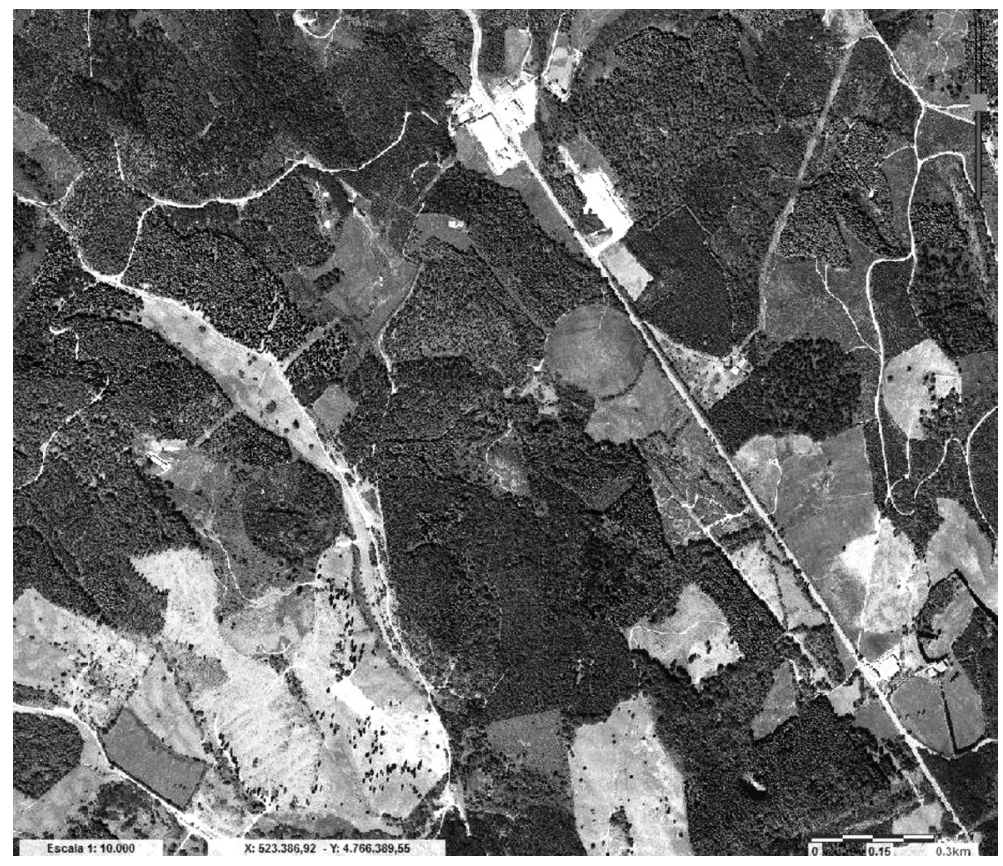

3. irudia

Denetariko kortak Zeanuriko Barazar inguruan (Bizkaia). 2015eko otsailaren 8an eskuratua http://apps.bizkaia.net/GRIT/

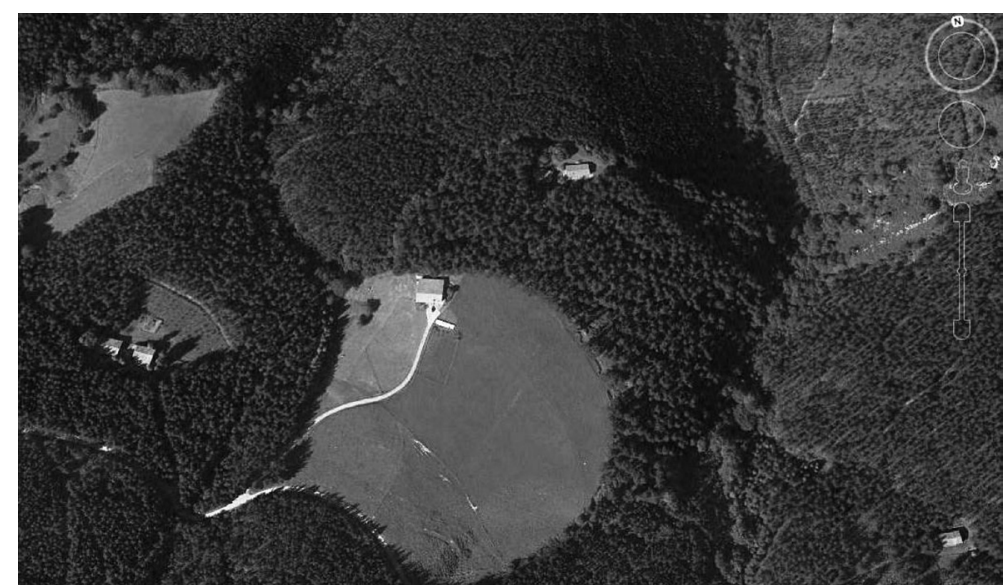

4. irudia

Okiz baserria korta batean (Munitibar-Arbatzegi-Gerrikaitz). 2015eko otsailaren 8an eskuratutakoa, https://www.google.es/intl/es/earth/index.html 


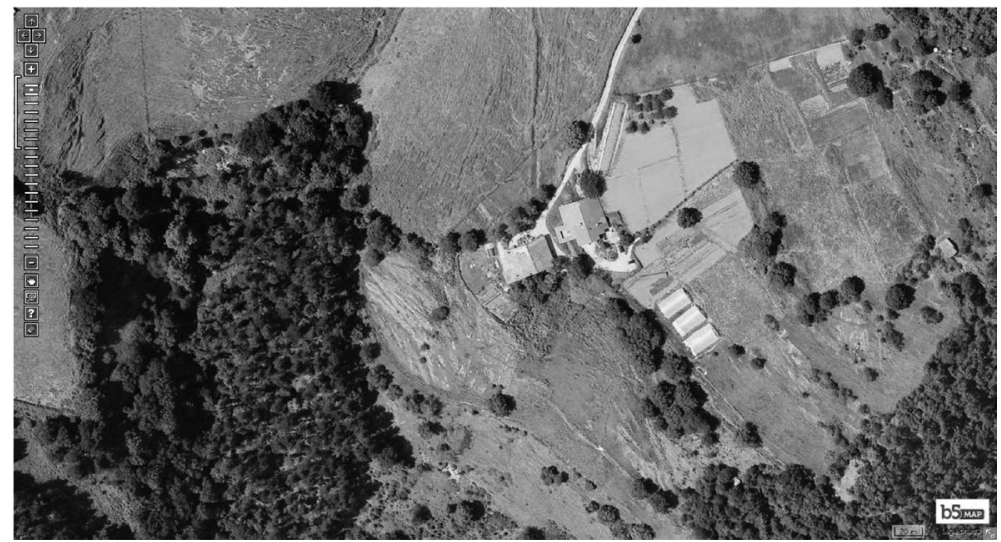

5. irudia

Beizamako Amenabar Goikoa eta Behekoa baserriak (Gipuzkoa). Saroien ertzak zuhaitzek zehazten dituzte, 2015eko urriaren 30ean eskuratua http://b5m.gipuzkoa.eus/b5map/r1/eu/mapa/lekutu/D_A13982/geruza/ortofotoa

\section{HAINBAT PROPOSAMEN TOPONIMIA LANTZEKO BIGARREN HEZKUNTZAN}

Laburki bada ere, euskal deitura askoren erlazioa baserri izenekin zein den azaldu ondoren, eta hauena kortekin, saiatuko gara gure proposamena adierazten, egin daitezkeen jarduera batzuk Bigarren Hezkuntzako gazteek ikas dezaten iturri historiko desberdinekin lan egiten eta, horrela, ezagutza sozio-historikoa eraiki dezaten.

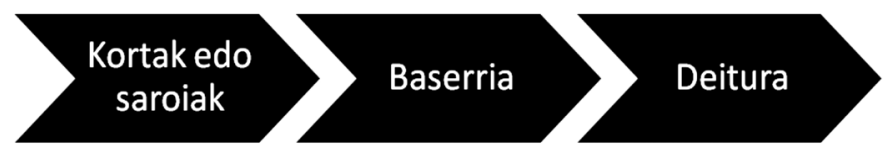

6. irudia

Euskal deitura askoren sorreraren bilakaera

Gure egitasmorako internet askean aurki daitezkeen materialak erabiliko ditugu, edozeinentzako eskura daudenak. Internet gure artean dago eta gazteek ikasi behar dute sareaz baliatzen ikaskuntza eraikitzeko. Baina informazioaren sareen sarea den horretan badago EAEko instituzioek herritarren esku jarritako eskaintza zabala, ikertzaileek darabiltena eta eskolara ailegatu ez dena.

Ezinbestekoa da gazteek internet erabiltzea informazio iturri gisa, jakin mina asetzeko, ikertzeko eta arrazoitzeko gaitasuna lortzeko. Estudioek 
kontrakoa diote. Euren kasa denbora-pasa moduan ei darabilte. Informazio iturri gisa, irakasleek aginduta, eskolako lanak egiteko, ia landu gabe, aurkiturikoa kopiatu eta itsatsita (Albero, 2002). Aldarte honetan irakasleak bitartekaritza lana egin behar du, ikaskuntza ahalbideratu eta trinkoa izan dadin, estrategia didaktikoak eta jarduerak diseinatu behar ditu, ikasleentzako esperientzia esanguratsuak izan daitezen. Informazioa transmititu beharrean, ikasleak trebatu behar ditu informazioa erabiltzen, benetako ikaskuntza burutu dezaten (Bernete, 2010).

Gure proposamena helburu hori lortzeko ere pentsatuta dago, pertsonaren identitatetik abiatuta eta informazio iturri fidagarriak erabilita. Eusko Jaurlaritzak badu sarean atari bat herritar ororen eskura: Euskadiko Artxibo Historikoa (http://eah-ahe.org/default.php), zeina den Euskadiko Artxibo Sistema Nazionalean sartzeko ataria eta erakusleihoa. Artxibo-sistema publiko eta pribatuek osatzen dute egitura hau eta atal desberdinetan antolatuta dago. Dokuklik deritzan webean (http://dokuklik.snae.org/) informazioa 3 bilatzaileren bitartez eskura daiteke. Bata Badator da (http:// dokuklik.snae.org/default.php) eta hor daude $« 400$ artxibo-funtsetan baino gehiagotan bildutako 550.000 dokumentuen erreferentziak», «XIII. mendetik XIX. mendera arteko aldian Euskadin zeuden estamentu, gremio, korporazio eta administrazio guztiei buruzko informazioa». Beste bat Luis de Salazar y Castro errege kronikariaren (1658-1734) bildumaren indizea da (http://dokuklik.snae.org/salazar.php), «Europako XVIII. mendeko erudizioaren altxorretako bat» eta ia 60.000 idazpen deskribatzaile dituena. Hirugarrena, gure asmorako interesgarriena dena, E.A.E.ko Eliza Katolikoaren hiru elizbarrutietako agiri sakramentalen datu basea dago (http:// dokuklik.snae.org/sacramentales.php), 1900 arte bataiatu, ezkondu eta hil zirenen idazkunak (5.600.000 agiri).

Ikerketari ekiteko, nahikoa da zehaztea XXI mendeko lagun baten lotura 1900 arteko arbasoekin. Irakasleak gidatuta, ikasleek bilatzailea erabiltzen ikasi beharko dute, beharrezkoak diren datuak sartzen eta, karaktere batzuen ordez, komodinak usatzen ere bai. Adibidez, zuhaitz genealogikoa egitea erabakiz gero, nahiz belaunaldi gutxi batzuetakoa izan, gazteen harridura sortuko dugunaren zalantzarik ez dugu. Deskubrituko dituzte historialari profesional batentzako garrantzi bako eta hutsalak diren datuak, baina nerabeari iragana hobeto ulertzen lagunduko diotenak. Esaterako, ikertzeko moduko gaiak lirateke: garai desberdinetako pertsona izen arruntenak, familiako seme-alaba kopurua, umeen hilkortasuna, ezkongaien adina, hildakoena, guraso bakarreko familiak, aita ezagun gabeko umeak, sasikoak. Ez lirateke datu estatistiko hotzak izango, euren familiarenak baizik.

Deituren bilaketa, berriz, beharrezkoak diren komodinak erabilita, dataren eta herriaren arabera ere egin daiteke. Adibidez, burutuko bagenu bilaketa orokor bat bataio, ezkontza edo heriotzarena, programak berak ordenatuko lituzke emaitzak kronologia eta herria kontuan izanda. Hori horrela, 
deitura desberdinak taxutu daitezke antzinatasunaren arabera, mapan kokatu, estatistika desberdinak burutu eta gaur egun Espainiako Erresuman zenbat lagunek daramaten ere jakin daiteke, Espainiako Estatistikako Institutu Nazionalaren hurrengo aplikazioan kontsultatua: http://www.ine.es/ apellidos/inicio.do. Jabetu ahal izango dira zenbat aldaera izan dituen euren abizenak denboran zehar, eurak guztiz normalizatutako ortografiaz idazten dutena. Batzuetan ortografia izan daiteke aldaeron kausa, beste batzuetan eskribauren baten edo transkribatzaileren baten akatsa, inoiz aldatu egiten dira gurasoen eta seme-alaben artean, karaktereren bat galdu edo gehitu eta, finean, aldatu. Horrelakoak ikusten ohiturarik ez dutenentzako oso harrigarriak suertatzen dira. Oso gomendagarria litzateke aldaeren zerrenda eta datarena egitea. Baita esangura asmatzea ere.

Goazen orain lan honen azken xedera, hots, deituren, izen bereko baserrien eta korta edo saroien arteko erlazioa zehaztera. Argi badago jatorrizko etxe bat egon zela haren jabeei edo han bizi izan zirenei deitura emateko balio izan zuena, nola ezarri dagoen lotura haren eta bakoitzaren abizenarekin? Erruz eta erraz aurki daiteke informazio genealogikoa, bai liburu formatuan edo internet bidez. Gure proposamen hau burutu ahal izateko, dagoen material onenetarikoa da Gure abi izenak: Araba, Bizkaia eta Gipuzkoa (Rementeria, 2015) 10.000 erreferentzia baino gehiagorekin, alfabetikoki ordenatuta eta etengabe gaurkotuta. Deituren informazioa eskaintzeaz gain, baserria zein herritan zegoen eta aurkitutako data zaharrenaren berri ere ematen du, deituraren jabearen izena eta artxiboko erreferentziarekin batera.

Bere arbasoak zeintzuk ziren zehaztu ondoren, ez da bat ere nekeza deitura eman zien jatorrizko etxera hurbiltzea. Kartografia konbentzionala oso lagungarria izan daiteke. Kartografia historikoa ere bai (7. irudia). Eta ezinbestekoak lirateke interneten dauden debaldeko tresnak.

Gazteei irakatsi behar diegu sarean edonoren eskura dauden tresnen bitartez lan egiten, horretarako trebatzen eta eskaintzen dituzten aukerei etekina ateratzen. Hala nola, Google Earth, https://www.google.es/intl/es/ earth/index.html, Google maps, https://www.google.com/maps, Sigpac, http://sigpac.mapa.es/fega/visor/, edo espezifikoagoak diren Geo Euskadi bisorea, http://www.geo.euskadi.net/s69-bisorea/eu/x72aGeoeuskadiWAR/ index.jsp?lang=eu, http://apps.bizkaia.net/GRIT/ edo http://b5m.gipuzkoa. eus/web5000/. Erreminta horiei esker, espazio geografikoaren satelite bidezko imajinak miatzeko eta ikusteko aukera dago, inguruaren analisi globala egiteko, ikasleak berarekin identifika daitezen eta horren gainean ikaskuntza eraiki dezaten (Luque, 2011).

Korta edo saroien eta baserrien jatorriaren gaineko azalpen labur baten ostean, sareko tresna horiek usatuz egin daitezkeen ariketa edo jarduera batzuk bideratu daitezke forma biribil horiek aurkitzera eta antzematera, baserri bihurtu ziren ala ez frogatzera, zein herritakoak diren, inguruaren deskribapena egitera, eskalak eta koordenatu geografikoak zehaztera, he- 


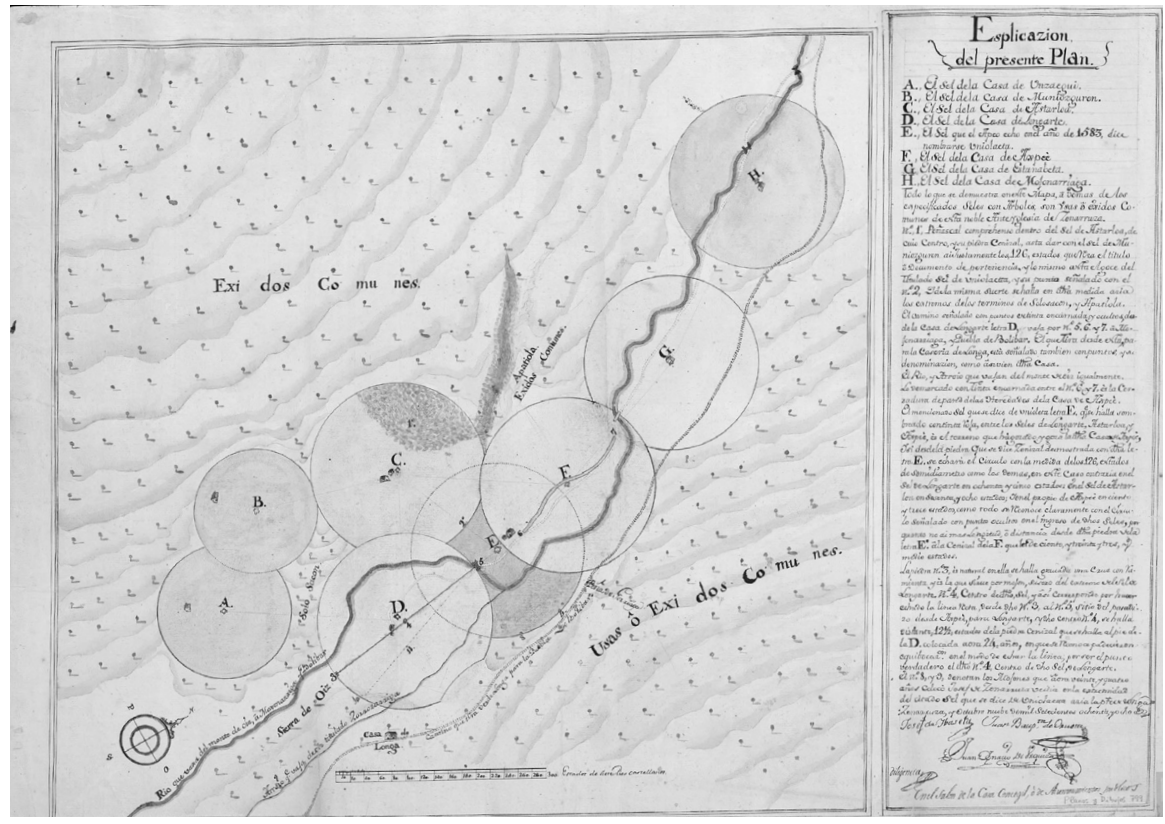

7. irudia

Ziortzako Kolegiatak zituen korta batzuk, euren baserri eta haustarriekin, lur komunalen erdi-erdian. $1.788 \mathrm{ko}$ planoa. Archivo de la Real Chancillería de Valladolid, ES.47186.ARCHV/6.6//PLANOS Y DIBUJOS, DESGLOSADOS,799. 2015eko irailaren 15ean eskuratua: http://pares.mcu.es/ParesBusquedas/servlets/Control_ servlet?accion $=3 \& \&$ txt_tipo_busqueda $=d l \& t x t \_b u s q u e d a=\& t x t$ correo=S\&txt_id_desc_ud=1592767

rriguneetatik gertu ala urruti dauden, nekazaritza, abeltzaintza ala basogintzarako diren. Edo besterik ezean, korta, gorta, saroi etab. toponimoen konposizioan dauden identifikatzera.

Oso interesgarria ikasleekin lantzeko, eta eskolan apenas presentziarik duena, jabetza pribatuaren gaia da, kortak izan zirelako lur komunaletan egin ziren lehenengo pribatizazioak. Jabetza pribatuaren kontzeptua, dirua edo kargu publiko batena moduan, errealitate sozial eta instituzional konplexua da. Searlek (2005) dioskun moduan, hiru nozio primitibok bat egiten dute hala izan dadin. Hauek dira: kolektibitate batek hala gura izatea, edozein gizatalderen oinarri dena bestalde, funtzio zehatz bat esleitzea eta estatus bat esleitzea, azken hau izanik naturan gertatzen denetik bereizten duena. 
Eta jabetza pribatuaz ari garenez, edozein hormak edo mugarrik, benetan harriak baino ez direnak, muga estatusa hartzen dute kolektibitateak hala aitortzen baditu, berez ez dutelako. Noiz da harri bat mugarri? Gizatalde batek mugarri izaera ematen dionean. Noiz jazo zen gertaera hori? Noiz hartu zuen harriak mugarri estatusa? Oso gaitza erantzuteko, noiz gertatu zen bataren eta bestearen arteko trantsizioa, segurutik polito polito izango zena. Eta nahikoa ez denez gizatalde batek onartzea estatus hori, derrigorra da horren froga ofiziala egotea, jabetza titulua izan daitekeena, erakunde ofizial batek emana, hau ere gizataldeak onartua.

Esandakoaren ildotik, galdetuko diegu ea bere izena daukan baserri etxearen jabeak diren. Salbuespenak salbuespen, gehienek emango duten erantzuna ezezkoa izango da. Ea euren burua aurkezten dutenean, zer dela eta esaten duten eurena ez den etxe batekoak direla. Ea dakiten arbasoak noiz joan ziren bertatik eta inoiz baserri horren jabe izan ote ziren. Ea familiak gordetzen duen egoera horien oroimenik.

Jasoko diren ihardespenak ez dira segurutik aldekoak izango. Eta burubide kontrafaktiko bat egitera animatuko ditugu (Domínguez, 2015), zorroztasun eta zehaztasunaz defenditzeko burutuko duten hipotesia, irudikatzerakoan zer gerta zatekeen euren arbasoek jatorrizko etxea utzi ez balute beste leku batera joateko.

Eta azkenik, enpatia historikoa gara dezaten (Domínguez, 2015), modu librean birsortu beharko dute lursail biribil haien banaketaren hasierako prozesua abeltzain familia batzuen artean. Zergatik egin zuten? Nortzuk? Jabe kopuru zehatz bat ote zuten gogoan? Nola antolatu zuten prozesua? Zergatik erabakiko zuten sail biribilak izatea eta ez karratuak, gaur egungo gehienak diren moduan?

\section{ONDORIOAK}

Toponimiak eta oikonimiak ia presentziarik ez duten arren E.A.E.ko curriculum ofizialetan, bistan dago aukera anitz eskaintzen dutela Bigarren Hezkuntzako edo Batxilergoko ikasleei iragana gerturatzeko, historikoki pentsatzen ikas dezaten, euren errealitatetik abiatuta, beren identitatetik. Guk luzatutako proposamena ez da inolaz ere osorik zertan egin behar, zatika zein eraldatuta burutu daiteke. Eta irakasleak ongien irizten dionean, eguneroko praktikan uztartuta, berak gidatuta.

Gerta daiteke, ikasle taldearen arabera, ez izatea aukera askorik euskal abizenak ikasbide bihurtzeko. Beti izango ditugu inguruan, auzoan, herrian, hirian pertsona eta pertsonaia esanguratsuak hori egin ahal izateko. Eta hala ez bada, nazioartean ere badaude euskal deitura daukatenak; oso erakargarriak, gainera. Futbolariak direla, ziklistak, kirolariak, politikariak, santuak, erreginaren bat, ongileak, aktore-aktoresak, zinegileak, kazetariak, musikariak, eta abar luze bat. 
Eta aprobetxa daiteke ere beste deitura batzuen inguruko jatorriaz mintzatzeko edo, kontrako bidea eginaz, ikasleentzako ezagunak diren baserri izenen inguruan aritzeko.

Eta korta edo saroiak direla eta, pribatizatu zirenetik mendeak eta mendeak pasatu dira eta ez alperrik. Jabetzak izan dituzten gorabeherak ez dira makalak izan. Edo zatitu direlako edo jabetzak kontzentratu direlako edo berrantolatu direlako, batzuek ez dute gorde forma biribil haien arrastorik ere. Baina bai kontserbatu dira bere osaeran korta, gorta, saroe, saroi, solo, soro hitzak dituzten toponimoak eta horiek samur topa daitezke lekuko mapa arruntetan ere eta, zer esanik ez!, aipaturiko kartografia digitalean.

Bukatzeko, eskaini dugun proposamen honen bidez, aldarrikatu nahi izan dugu toponimiaren eta oikonimiaren baliagarritasuna aspaldiko eta egungo errealitate historiko eta geografikoak estudiatzeko, irakasleek aintzat hartu beharko lituzketenak. Berariazkotasuna eta, aldi berean, egunerokotasunean arrunt izan arren, erakargarria izan daitekeelako ikasleen jakin-mina pizteko, arrazoitzen eta ikertzen ikasteko.

The paper presents a proposal for Social Sciences teaching-learning in Secondary Education. It starts with current Basque surnames that come from the name of the «baserriak», the traditional homes of the Basque provinces of Bizkaia, Gipuzkoa, north Alava and Navarra and the French Basque Country. In times difficult to be determined, the communal lands began to be privatized, adopting the form of circular plots. The documentation written in romance language calls these plots «sel», a word of pre-Roman origin that was also kept in Basque language. Sels gave birth to a number of place names some of which were used to name the house built on these particular lands. These farm names in many cases also provided the surnames for individual Basque families living there. Our proposal identifies existing seles, displays a number of historical and geographical online tools and offers students a number of activities for building a socio-historical knowledge well related to their own reality.

Keywords: Teaching-learning of Social Sciences, place names, house names, Basque surnames, private property, secondary school, ICTs. 
El artículo presenta una propuesta de enseñanza-aprendizaje de las Ciencias Sociales para Educación Secundaria, tomando como punto de partida los apellidos vascos que tienen su origen en el nombre del caserío, es decir, la casa tradicional de las provincias de Bizkaia, Gipuzkoa, norte de Álava y de Navarra y el País Vasco Francés. En época difícil de determinar los terrenos comunales comenzaron a privatizarse, adoptando la forma de parcelas circulares. La documentación en romance los denomina seles, un vocablo de origen prerromano y en euskara han dado lugar a una serie de topónimos, algunos de los cuales pasaron a nombrar al caserío que se construyó en los mismos. Y los que habitaron en dichos caseríos lo adoptaron como patronímico. En la propuesta se ofrecen una serie de herramientas histórico-geográficas asequibles en Internet y se sugieren actividades para que el alumnado construya un conocimiento socio histórico conectado con su propia realidad.

Palabras clave: Enseñanza-aprendizaje de las Ciencias Sociales, toponimia, oiconimia vasca, apellidos vascos, propiedad privada, Educación Secundaria, TIC.

Cet travail présente une proposition de l'enseignement-apprentissage des sciences sociales pour l'enseignement secondaire, en prenant comme point de départ les noms basques qui ont pour origine le nom de la ferme, qui est la maison traditionnelle des provinces de Biscaye, Guipúzcoa, au nord d'Alava et Navarre et le Pays Basque Français .En temps difficiles de déterminer les terres communales ont commencé à être privatisées, sous forme de parcelles circulaires. La documentation écrié en lange espagnole appel ces parcelles «sel », un mot d'origine préromaine. En basque ont abouti à un certain nombre de noms de lieux, dont certains ont servi à appeler la maison que a été construite sur eux. Cela a servi comme un nom patronymique aux habitants de ces fermes. Notre proposition offre un certain nombre de outils historiques et géographiques abordables en ligne et quelques suggestions d'activités pour les étudiants, à construire une connaissance socio-historique lié à leur propre réalité.

Mots-clé: L'Enseignement-apprentissage des Sciences Sociales, la toponymie, l'oiconymie, les prénoms basques, la propriété privée, Education Secondaire, TIC. 


\section{ERREFERENTZIA BIBLIOGRAFIKO ETA ARTXIBISTIKOAK}

Albero, M. (2002). Adolescentes e Internet. Mitos y realidades de la sociedad de la información (1). Zer: revista de estudios de comunicación / komunikazio ikasketen aldizkaria, Vol. 7, n. $^{\circ} 13,177-191$.

Barros, C. (2008). Propuestas para el nuevo paradigma educativo de la historia. Sarmiento: Anuario galego de historia da educación, 12, 127-152.

Bedoya, E. (2006). Toponimia: Herencia cultural. Revista Herencia, 19 (1). 9-31.

Bernete, F. (2010). Usos de las TIC, Relaciones sociales y cambios en la socialización de las y los jóvenes. Revista de Estudios de Juventud, (88), 97-114.

Calaf-Masachs, R. (2009). Didáctica del patrimonio. Epistemología, metodología y estudio de casos. Gijón: Trea.

Comerci, M. E. (2012). Espacios y tiempos mediados por la memoria. La toponimia en el oeste de La Pampa en el siglo Xx. Corpus, 2/2, 2-24.

Comes-i-Solé, P. \& Dantí-i-Riu, J. (2003). Rastres. Una eina pedagógica per al coneixement de la historia local i comarcal. Ponències. Revista del Centre d'Estudis de Granollers, 11-25.

Domínguez-Castillo, J. (2015). Pensamiento histórico y evaluación de competencias. Barcelona: Graó.

Estepa, J. (2001). El patrimonio en la didáctica de las ciencias sociales: obstáculos y propuestas para su tratamiento en el aula. Iber. Didáctica de las Ciencias Sociales, Geografía e Historia, 30, 93-105.

Estepa, J., Domínguez, C. \& Cuenca, J.M. (1998). La enseñanza de valores a través del patrimonio. In A. M. Fililla (coord.) Los valores y la didáctica de las ciencias sociales. Lleida: Universitat de Lleida, 327-336.

Estepa-Giménez, J., Cuenca-López, J. M. \& Martín-Cáceres, M. J. (2011). Enseñar y aprender las Sociedades Actuales e Históricas a través del Patrimonio en la Educación Primaria. In R. López-Facal, L. Velasco-Martínez, V. M. Santidrián-Arias \& X. A. Armas-Castro (Coords.). Pensar históricamente en tiempos de globalización: actas del I Congreso Internacional sobre enseñanza de la historia, 243-254.

Ezkurdia-Arteaga, M. G., Pérez-Urraza, K., Bilbao-Bilbao, B. (2006). Curriculuma eta testu liburuetako edukia. Jakin, 153, 89-100.

Friera-Suárez, F. (1992). Utilidad de la toponimia para el conocimiento del entorno. Lletres asturianes: Boletín Oficial de l'Academia de la Llingua Asturiana, 45, 35-44.

Galé, P. (2007). Toponimia ikerketak. Fontes Linguae Vasconum, 104, 161-172.

Gómez-Gonçalves, A., Sevilla-Álvarez, J. \& Fernández-Álvarez, R. (2015). Hacer emerger la diversidad de espacios y los lugares vulnerables a través de un recurso de escasa visibilidad en el currículo de educación primaria: la toponimia. In Ana M. ${ }^{a}$ Hernández-Carretero, Carmen-Rosa García-Ruíz \& Juan-Luis de-la-Montaña-Conchiña (ed.). Una enseñanza de las ciencias sociales para el futuro: recursos para trabajar la invisibilidad de personas, lugares y temáticas. Cáceres: Universidad de Extremadura \& Asociación Universitaria de Profesores de Didáctica de las Ciencias Sociales, 183-192.

Gogeascoechea, A; Juaristi, J; Moro, I. (2009). Del uso común del monte a la propiedad privada: introducción al estudio de los seles en Bizkaia. Lurralde, 32, 15-46. 
- (2010) El proceso histórico de ordenación de los seles en Bizkaia: estandarización de las superficies y cambios en los usos del suelo. Lurralde, 33, 37-95.

Gonzalez, N. \& Pagès, J. (2005). La presencia del patrimonio cultural en los libros de texto de la ESO en Cataluña. Investigación en la escuela, 56, 55-66.

Ituláin-Irurita, J. (2005). Oiconimia del valle de Unciti. Cuadernos de etnología y etnografía de Navarra, 80, 85-178.

Le Goff, J. (1983). Tiempo, trabajo y cultura en el Occidente Medieval. Madrid: Taurus.

Lleonart, A. (2008). Conèixer l'entorn a través de La toponímia. In Segon Congrés Català de Geografia. 'El mapa com a llenguatge cartogràfic. Institut Cartogràfic de Catalunya, 269-280).

López-Cruz, I. (2013). La Educación Patrimonial en los libros de texto de Ciencias Sociales, Geografía e Historia, In Estepa-Giménez, J. (Ed.). La Educación Patrimonial en la Escuela y el Museo: Investigación y Experiencias. Huelva: Universidad de Huelva, 225-236.

Luque, R. (2011). El uso de la cartografía y la imagen digital como recurso didáctico en la enseñanza secundaria. Algunas precisiones en torno a Google Herat. Boletín de la Asociación de Geógrafos Españoles, 55, 183-210.

Mas-i-Miralles, A. (1999). Introducció a la toponímia (anàlisi i proposta Didàctica). Revista del Vinalopó, 2, 7-25.

Pérez-Urraza, K., Ezkurdia-Arteaga, M. G., Bilbao-Bilbao, B. (2015). El paisaje: un concepto básico en el currículum desarrollado en los libros de texto del País Vasco. Espacio, Tiempo y Educación, v. 2, n. 2, 225-242.

Rementeria, I. (2015). Gure abi izenak: Araba, Bizkaia eta Gipuzkoa. https://www. academia.edu/11427666/Gure_abi_izenak_Araba_Bizkaia_eta_Gipuzkoa

Rementería-Arruza, D. \& Quintana-Peña, R. (2010). Los seles de BusturialdeaUrdaibai. Paisaje, cultura y etnografía. Lorra Kultur Elkartea Ondare Etnografikoa.Vitoria-Gasteiz: Servicio Central de Publicaciones del Gobierno Vasco.

Ros, A. (2013). Euskal deituren jatorriari buruzko gogoetak. Reflexiones sobre el origen de los apellidos vascos ( $2^{\mathrm{a}}$ parte). Antzina, 18, 34-48.

Særheim, I. (2004). Toponymy and teaching: cultural history and cultural experience. Onoma, 39, 217-241.

Salaberri-Zaratiegi, P.; Zubiri-Lujanbio, J. J. (2009). Euskal deituren jatorria eta etxe izengoitiak. Anuario del Seminario de Filología Vasca «Julio de Urquijo», XLIII, 819-830.

Santana, A. (2011). El Cinturón Verde, un paisaje circular: los seles. In Bilboaldeko Ingurune Berdea / Cinturón Verde del Bilbao Metropolitano. Bilbao: Diputación Foral de Bizkaia, 131-146.

Santana, A.; Larrañaga, J. A.; Loinaz, J. L. \& Zulueta, A. (2002). Euskal Herriko baserriaren arkitektura / La arquitectura del caserío de Euskal Herria, Vitoria-Gasteiz: Servicio de Publicaciones del Gobierno Vasco.

Sanz-García, V.F. de J. (1992). Arquitectura tradicional y entorno geográfico. Tabanque: revista pedagógica, 8, 129-150.

Searle, J. (2005). What is an institution? Journal of Institutional Economic, 1:1, $1-22$.

Torres, M. T. (1995). Toponímia i escola: una proposta didàctica. Eivissa, 26, 20 23. 
Tort-i-Donada, J. (2001). La toponímia com a camp de coneixement interdisciplinari: algunes bases teóriques i epistemològiques per a l'estudi dels noms de lloc. Scripta Nova: Revista electrónica de geografia y ciências sociales, 5, 79104.

Tort-i-Donada, J. (2004). El paisaje como «pedagogía del territorio». Didáctica geográfica, 6, 133-153.

Trigueros-Cano, F. J.; Ortuño-Molina, J. \& Molina-Puche, S. (2015). La percepción del alumnado de educación secundaria sobre el desarrollo del pensamiento histórico en el proceso evaluador. Revista de Estudios Sociales, 52, 69-86.

Ubieto-Arteta, A. (2007). Propuesta metodológica y didáctica para el estudio del patrimonio. Zaragoza: Universidad de Zaragoza.

Valenzuela-Valdivieso, E. (2010). ¿Es posible aprender Geografía a través de la toponimia? Investigación Universitaria Multidisciplinaria: Revista de Investigación de la Universidad Simón Bolivar, 9, 16-26.

Valls, R. \& López-Facal, R. (2010). ¿Un nuevo paradigma para la enseñanza de la historia? Los problemas reales y las polémicas interesadas al respecto en España y en el contexto del mundo occidental. Enseñanza de las Ciencias Sociales, $10,71-81$.

Villalón, G. (2013). Estrategia para formación de la cultura toponímica local desde el proceso educativo escolar en secundaria básica. Revista Iberoamericana de Evaluación Educativa, 6 (1), 77-94.

Zaldua-Etxabe, L. M. (2006). Saroiak eta kortak. Ed. Luis María Zaldua Echave.

Archivo Histórico Nacional, Consejo de Órdenes, OM-CABALLEROS_SANTIAGO, Exp. 523, 3v-4r.

Archivo de la Real Chancillería de Valladolid. Pleitos Civiles. Escribanía Varela. Pleitos Fenecidos. C 2416/6.

http://apps.bizkaia.net

http://b5m.gipuzkoa.eus

http://www.geo.euskadi.net/s69-bisorea/es/x72aGeoeuskadiWAR/index.jsp

http://dokuklik.snae.org/

http://pares.mcu.es/

http://sigpac.mapa.es/fega/visor/

http://www.euskadi.eus/bopv2/datos/2007/11/0706182a.pdf

http://www.euskadi.eus/bopv2/datos/2010/04/1002109a.pdf

http://www.hezkuntza.ejgv.euskadi.eus/r43-5473/es/contenidos/informacion/dia2/

es_2023/adjuntos/decretos_curriculares/dc_educ_basic_c.pdf

http://www.ine.es/apellidos/inicio.do

https://www.google.com/maps

https://www.google.es/intl/es/earth/index.html, 